\title{
ERRORS WITH REFERENCE TO MEXICO AND EVENTS THAT HAVE OCCURRED THERE
}

\author{
By Henry lane Wilson,
}

Former Ambassador of the United States to Mexico.

\section{The Character of the Government of General Diaz}

Diaz was not a tyrant, but a benevolent autocrat who understood the Mexican people and knew them to be unfitted for self-government. Though not elected by constitutional methods, he governed according to law. He ruled Mexico for thirty years with a hand of iron, but possessed withal undeviating personal honesty, loyalty to obligations and a profound patriotism, together with a lofty conception, as to Mexico's needs and future. His foreign policy was clear and fixed from the first days of his power. It consisted, among other things, of the cultivation of the friendliest relations with the government of the United States coupled with the invitation to American capital and American energy to go thither and develop the marvellous resources of the country, affording them generous profits but reaping in return much greater ones for Mexico.

He had two great domestic policies: First, the development of the material resources of the country; second, the quickening of the moral life of the nation. The first of these policies he accomplished with a high measure of success. The second he would have accomplished but for the undermining influences of advancing years and the realization that the task was beyond his endurance and power. If Diaz had carried the torch of enlightenment into the dark places of Mexico, the history of the last three years might have been differently written. He covered Mexico with a network of railways; he developed her resources by concessions and by encouragement to foreign capital; he fostered her manufacturing, mining, agricultural, and commercial interests; built hospitals and innumerable public institutions; established her credit at home and abroad; and, with his army and rural police, made life as safe on a Mexican highway as on one of the public thoroughfares of the state of Massachusetts. He did more than this. Witb the materials which he had at hand he 
tried to establish justice, and no man whocould present to him an honest cause ever suffered through a miscarriage of justice; and no man who observed the law and kept the peace needed to fear his avenging hand. The legend, however, existed that those who broke the law, that those who committed crimes, must pay the penalty, and this made peace.

\section{Diaz was not Overthrown by Madero, but by a Universal Public} Sentiment which Madero neither Created nor Represented

The government of Diaz was not overthrown by Madero; it collapsed and on its ruins Madero, who represented only a small fraction of the active opposition, rode into power through the default of any other organized movement.

The vast majority of Mexican public opinion was hostile to Madero from the first days of his government, and this hostility augmented as it became evident that his administration was insincere in its promises and incompetent in the performance of its obligations. Madero came into power pledged to a platform which declared for free press, free elections, free lands, free education, and a free judiciary, but after more than a year of his administration not a single pledge of his altruistic program had been kept. A free press existed neither in theory nor in fact. Of the metropolitan newspapers three were owned by the government, and the editors of five were in jail. The press and the international news service were censored and only that which pleased the government was sent abroad. In the matter of elections, the government interfered with every gubernatorial election from the Rio Grande River to the boundary of Guatemala, and it used all its power and influence to elect a friendly legislative body. Pledged to free and universal education, the government did not appropriate for educational purposes a single dollar beyond the amount already established by precedent. Neither was a single additional school-house built, nor an additional opportunity afforded a Mexican child to receive education. To the great and preëminent problem of furnishing lands to the people through some intelligent system of redistribution no attention whatsoever was paid, and when Madero fell not a single acre of land had been distributed, nor did there seem to be the slightest probability of any effort in that direction. In the last days of the government a profound pessimism suc- 
ceeded the altruism which had been so bravely heralded in the earlier and more sanguine days. The leader of the revolutionary protest against the despotism of Diaz became himself a despot, practicing all the forms of tyranny against which his revolution and bis election were protests; the dreamer of Coahuila, who essayed the rôle of Moses, shriveled rapidly to the dimensions of a Castro. Thus, after the sacrifice of thousands of human lives, the destruction of vast material interests, aggravation of the condition of the poorer classes, and desolation and ruin spread over a third of the area of the republic, the Mexican people discovered that their lives and their property were subject to the same type of despotism which had aroused a national protest against Diaz, and that the dangers and difficulties of the hour were vastly increased by the impotence of the government and its apparent inability to maintain the national prestige and credit.

\section{The Supposition that Madero was Elected by Constitu'ional Methods and by the Majority of the Mexican People}

Madero received a total vote of 19,987 , out of a population of $15,000,000$ people. There is no such thing as a constitutional method in Mexico. There is no machinery for carrying out the national will through democratic channels. There are no precedents to guide the Mexican population in the exercise of sovereignty, and the people themselves are totally unable to distinguish between right and wrong, between an autocracy and a democracy. If left to their own inclinations they would choose an autocracy.

\section{The General Belief that the Madero Government was pro- American}

At the close of the Taft administration relations between the United States and Mexico had become severely strained. At the beginning of the revolutionary government there were in Mexico somewhere between fifty and seventy-five thousand American citizens and American capital invested to the extent of probably a billion of dollars. As the Madero government continued in power, it became evident, not only to the official representative of the government of the United States in Mexico, but to all observing foreigners, that there existed a strong anti-American sentiment among a large number 
of the more ignorant part of the population of Mexico; a sentiment which, if not in some measure shared by the Mexican government, was at least not discountenanced nor reproved by it. In no single instance, that can be recalled, did an official under Madero voice an appreciation of the unselfish attitude of the American government and people, or express the smallest measure of gratitude for the material benefits which American intelligence and energy and American capital had bestowed upon Mexico. On numerous occasions, however, public orators, the press, and all the organs capable of influencing public opinion, were busily engaged in inflaming the public mind and in rendering more unsafe the situation of Americans and their properties in Mexico.

This lack of sound and civilized public policy bore its fruit, as might have been expected, in a wide and indiscriminatory attack upon everything bearing the stamp of American origin. American interests honestly acquired, and on which vast amounts of capital had been expended, were everywhere attacked on baseless and absurd pretexts, by persons in collusion with friends of the government, and were harassed by confiscatory taxes and by the denial of the protection which the most elementary conceptions of government would afford them. American citizens, to a great number, were arrested on frivolous and insufficient charges, and incarcerated in filthy and unc:vilized jails, from which neither the protests of our own government nor the palpable and proven injustice of their imprisonment could release them. Scores of American citizens were foully and brutally murdered, and neither diplomatic representations, entreaties nor threats served to procure the trial or punishment of the offending criminals. The property of our citizens was destroyed, yet the Madero government turned a deaf ear to their complaints, and denied them that justice which it is incumbent upon all civilized nations to afford. To such an extent did this persecution grow that, at the time of Madero's fall, probably thirty thousand American citizens had been obliged to abandon their homes, their factories, their mines, and their haciendas, and return to the United States.

The American property confiscated or destroyed reached a sum of vast proportions, and yet from all indications the Madero government had no intention of recognizing its responsibility for the damage. The inability to secure adequate protection for American citizens, the unprovoked murder of many Americans, the failure on the part of 
the Mexican government to secure the arrest, detention and punishment of the murderers, the disposition of the executive to attack legally acquired American interests through trumped-up court processes, the arbitrary arrest and imprisonment of Americans on frivolous charges, the failure of local governments to remedy such abuses, the savage and barbarous character of the warfare-by all of these intolerable conditions our government was finally forced to take a decisive stand. Hence, on September 15, 1912, the embassy, under instructions from Washington, addressed to the Mexican government a note which not only evidenced the virility and alertness of the Taft administration, but induced the Madero administration to dispatch the minister of foreign affairs, Mr. Lascurain, to the United States with instructions, couched in general and vague language, to make concessions to Secretary Knox, and also incidentally to see President-elect Wilson for purposes unknown to the author but presumably connected with the policy towards Mexico of the administration which was about to come into power. This occurred coincidentally with the withdrawal of Señor Calero, Mexican ambassador at Washington, and his public announcement in connection with his resignation, that he had been instructed by the Madero administration systematically to misrepresent conditions in Mexico.

\section{Character of the so-called Constitutionalists and their Leaders}

The so-called constitutionalists are merely large organized bands of bandits who were in arms against the government of General Diaz, and then in arms against the government of Madero, and are now in arms against the government of General Huerta. These bandits learned of their new opportunities in the last days of the Diaz government; they improved them under the government of Madero; and they have now become professional bandits who loot to live and live to loot. The designation "Constitutionalist" has been assumed solely for the purpose of enlisting the sympathy of the Washington government, which should long ago have discovered the shallow pretense and mockery of the disguise. These people have no comprehension of the meaning of the word "democracy." Their idea of an election is a revolution, and they have no intention whatsoever of aiding in the maintenance of an orderly, peaceful, democratic republic. 
The duties of my position during nearly four years of arduous and responsible work in Mexico, have brought me frequently in contact with the methods of these northern brigands, and I may say without the slightest hesitation that, as a whole, they are not only entirely out of keeping with our conception of what an honest people struggling for liberty should be, but are mere natural savages dressed up in the habiliments of civilization. Of their chiefs and leaders it can only be said that their crimes are greater and their responsibility more heavy because of their greater intelligence.

Carranza, the dummy and opera bouffe president put forward by this band of outlaws, is an ineffectual politician. He is responsible for the massacre of Durango. He was chased out of the state of Coahuila by his subordinates, and he has remained until the last few weeks, by the order of Villa, in complete isolation in the state of Sonora. Whatever part he takes in coming events, the American public may understand that it is purely opera bouffe in character, and that, when he is not needed for spectacular purposes, his services will be promptly dispensed with.

Villa, the real leader of the revolutionary party, has been a bandit for twenty-five years, and has to his credit more than one hundred murders. He has pillaged and looted the larger part of the state of Chihuahua. He is responsible for the massacres of Juarez, Ojinaga, Chihuahua and Torreon, and he may be depended upon to murder and loot whenever he can do so with safety.

Aguilar, the third chieftain, was in arms against Diaz, and then in arms against Madero, and is now in arms against Huerta. His contribution to the cause of constitutionalism was the massacre of Victoria. The fourth in this galaxy of patriots is Zapata, who is responsible for the desolation and spoliation of the states of Morelas and Guerraro. Zapata is known to all the world. He has been in arms against Diaz, against Madero, and finally against Huerta, and will be in arms against any government established in Mexico City.

With these elements the Washington administration must deal when it shall have overthrown the government of General Huerta, and no government will be permitted to exist which has not the seal of their approval and support. 


\section{Character of the Mexican Population as a Whole}

The character of the Mexican population as a whole is very greatly misunderstood in the United States. At least 80 per cent of the population is of the indigenous races, without an abiding place except by sufferance, with no more than a nominal part or interest in the politics and affairs of the country, unable to read or write, who, while preserving the vices and traditions of their ancestors, have been made infinitely worse by the ingrafting of the vices of the white man and by the consciousness of a feeling of injustice arising from the realization that they are pariahs and outcasts. Here lies, in large measure, the root of the evil conditions and that which will constitute a menace for all time to come, unless righted by a strong and vigorous government moving on definite lines of policy with the sympathy, advice and assistance of those civilized powers which, instead of attempting to set up an altruistic republic among a people unfitted for it by education and tradition, may furnish those effective aids which will lead to a system of universal education, the implanting of sound political ideas, and a patriotism which shall be something higher and nobler than hatred of the foreigner.

\section{Character of Madero}

Madero was a man of imperfect education and vision. He was a disciple of the French school in politics and economics, but never gathered its threads of philosophy for practical application nor comprehended in the least the deep, practical common-sense which lies at the root of all French political opinion. He was a dreamer of dreams, and a singer of unknown songs which met with no echo. He came into power as an apostle of liberty, but he was only the man who happened to be in the public eye at the psychological moment. Remote from the great position where his misguided ambition carried him, he would, doubtless, have remained a quiet and simple country gentleman of benevolent ideals and blameless life. Clothed with the chief power of the nation, evil qualities, dormant in the blood or in the race, came to the surface and wrought ruin to him and to thousands upon thousands of the Mexican people. 


\section{Events of the Bombardment of the City of Mexico and the Overthrow of Madero}

With reference to the bombardment of the City of Mexico, which culminated in the overthrow of Madero, it may be useful to illuminate a few points which have been matters of public discussion.

1. The representations unofficially made to Madero urging his resignation by the American ambassador and the British, German, and Spanish ministers, with the approval of all their colleagues, were made after it was known that a large number of army officers under Huerta were untrue to the Madero government. Also they were made only after the military attache of the American ambassy had informed the ambassador that the citadel held by General Diaz could not be taken by the Madero government, even with the sacrifice of its entire military force. These representations reflected the views of all foreigners in Mexico City. They were made, not only for the purpose of saving the lives of foreigners, but for the purpose of saving the lives of Madero and his family.

2. These representations were enforced on the same day by similar representations from the Mexican Senate, and they were followed on the next day by similar representations from a committee of the army, at which time Madero killed with his own hand Colonels Riverol and Izquerdo. I believe this is not disputed. Following this act Madero was made prisoner by General Blanquet. Had he acted upon the advice given him by the members of the diplomatic corps and handed over his powers to Congress, the Mexican revolution would have avoided all the tragedies which followed.

3. After the overthrow of Madero was announced to the American embassy for transmission to the diplomatic corps, a new situation immediately developed. All civil power had ceased. Two hostile armies occupied the City of Mexico, which had been devastated by ten days of bombardment, during which the lives of some five to seven thousand people were sacrificed. In the poorer quarters of the city, thousands of people were starving. Bandits were beginning to appear in every quarter intent on pillage. Human life was safe nowhere. Some twenty thousand foreigners were depending upon the embassy for protection and for guidance. Fifteen hundred Americans had been brought out of the firing zone and furnished with homes in the immediate vicinity of the embassy which undertook to afford 
them protection and supply them with the necessities of life. Lights and water for the embassy had been cut off, and one side of the building riddled with bullets. The scarcity of food increased, and the difficulty of feeding the vast number of people dependent upon the embassy for supplies grew hourly greater. It seemed to the ambassador that his duty was clear, and he immediately sent, on his own responsibility, for General Felix Diaz and General Huerta to come to the embassy, as neutral ground, for the purpose of arranging, if possible, for some cessation of hostilities. Eight hours after the overthrow of Madero these generals came to the embassy. The ambassador had met these men only once before in company with his colleagues, but he was able after six hours of discussion-sometimes of a highly irritating character-to induce these men to agree to turn over their powers to Congress. This was done, and on the morrow the people of the City of Mexico resumed their peaceful occupations.

4. Madero died as the result of a military conspiracy formed for the purpose of avenging the deaths of General Reyes, General Ruiz, Colonel Riverol and Colonel Izquerdo. The embassy's investigations brought no certain conclusions except to indicate that General Huerta was in no way privy to the killing of Madero, but that it was his well-defined purpose to send him out of the country. At one time a train was prepared for this purpose, but when telegrams from some member of the Madero family to the military governor of Vera Cruz urging him to rise, were intercepted, Huerta decided it would be unwise to let Madero depart. The most that may be said of Huerta in connection with this crime, so repugnant to civilization, was that he did not take sufficient precautions to guard against it. Madero was killed in precisely the way it was related, namely, by his guards after an attack had been made upon the automobile. It may be mentioned here that Madero was being transferred from the guard house in the palace to the penitentiary at the request of the American embassy; which acted in the matter in response to Mrs. Madero's prayers that more comfortable quarters should be assigned to the ex-president.

5 . It is believed by a great many honest people that Huerta slew Madero for the purpose of succeeding him in the presidency, This is a chronological error. Madero had resigned and Huerta had succeeded to the provisional presidency before Madero was killed. Thus while Madero was violently overthrown, his death did not occur until after his successor had been chosen. 


\section{Legality of the Government of Huerta and its Support by Pub- lic Opinion}

The government of General Huerta was as legally constituted as any Mexican government in the past. President Madero and VicePresident Suarez resigned. Mr. Pedro Lascurain, the Madero minister of foreign affairs, then succeeded under the constitution to the presidency. He assumed the office and appointed as his minister of the interior, General Victoriano Huerta, and then resigned. General Huerta then took office in accordance with the provisions of the Mexican constitution, and his powers were approved by Congress without a dissenting voice. The government came into power accompanied by the hopes of fourteen million Mexicans who were not enamored of Huerta, but who were sick of disorder, blood and violence and the wasting of the national resources. These people wanted a government which would stand for law and order. They believed Huerta to be a man of the type of Diaz, who would be fearless and prompt in the protection of society and in the punishment of those who violated the law. Huerta is a soldier. He has spent his entire life in military service. He is an able, adroit, courageous man. His desire is to protect society and to restore peace, and he is not over particular as to the methods employed to accomplish this end. He will fight to the last, and if eventually overthrown will go down in the midst of the ruins.

\section{Errors of the Washington Administration}

1. The announcement of the new doctrine that governments owing their origin to violence would not be recognized by this government. This was an error for the following reasons:

$a$. It was announced before the President had access to the records of the department of state and the history of our foreign relations, which should have served as his guidance.

b. It was purely an expression of the President's personal views, being contrary to the traditions and precedents of this government since its existence.

c. It was uttered without foresight and without that comprehensive view of its effect on our foreign relations which should have obtained. This is made evident by the inconsistent attitude of the administration in refusing to recognize the administration of Huerta, 
and subsequently recognizing the new government of Peru-where the president had been deposed by violence and was in jail, and the minister of war had been assassinated-and by the recognition of the government of Haiti. These inconsistencies subject the administration to the charge of insincerity.

2. The refusal to recognize the provisional government of General Huerta. In taking this position this government was acting within its rights, but it nevertheless contributed to the discredit of a government which was endeavoring to restore peace and order in Mexico, and which had the support of ninety-eight per cent of the Mexican public and of the American and all other foreign colonies, as well as of all European governments. The consequences following the withholding of our recognition have been most grave. Our attitude has been interpreted and is now recognized as favoring and supporting rebels in arms against a regularly constituted government. It has fed the flames of rebellion, stimulated the revolutionary movement, and is responsible for the destruction of millions of dollars worth of property and thousands of human lives. It has financially ruined thousands of Americans, and it has afforded advantages to European commercial, manufacturing and exploiting interests, to the loss and detriment of those of the United States. It has excited the suspicion and hostility of every Latin-American country, has grievously affronted every European chancellery and has placed this nation in such imminent peril in its foreign relations with three great governments that it has found itself obliged to determine its course in a great international question by the pressing necessities of the difficult position which it has created rather than in response to the call of high national and moral obligations. It has forced a further distorted and amplified interpretation of the already exaggerated Monroe Doctrine, and launched us upon seas of imperialism from which no man may see the shore. Persistence in such a policy can be justified only by the supreme necessity of saving the pride and prest ge of an administration committed to a national blunder. It can therefore be justified only as a policy of "expediency" and not as one of "morals."

3. The dispatch of the Lind mission. The dispatch of Mr. Lind to Mexico, as the official representative of the President in dealing with the Huerta administration without the approval or consent of the Senate of the United States, was an act at variance with our precedents, and was an assertion of over-lordship toward the sovereign 
Mexican nation through direct though not armed intervention in its affairs. The representations made through Mr. Lind had already been made, under instructions from Washington, through the sworn and constitutionally appointed officer of this government, without success, and their repetition through the President's personal representative, a person without diplomatic character or training, was an act of needless offensiveness toward a friendly and sovereign state. The Huerta government was convicted of high crimes and misdemeanors upon $e x$ parte testimony. Huerta was told that he was unfit to be president and was asked to join in an expression of his own condemnation. Huerta's government was. furthermore asked to give guarantees for a constitutional election, whereas every person versed in Mexican affairs knows that a constitutional election is impossible in Mexico. Finally, the diplomatic maneuvers of the Washington government having been conspicuously baffled and defeated by the fearless Mexican president and his astute minister of foreign relations, $\mathrm{Mr}$. Gamboa, the administration made an irreparable mistake in retaining Mr. Lind in Mexico, after his mission had terminated, thus further irritating the Mexican government, exposing our own government to additional ridicule, and the unfortunate Mr. Lind to the dubious delights-though assured safety-of the seaport of Vera Cruz.

4. The attempt to discred.t European nations accredited in Mexico, and to misrepresent their attitude with reference to recognition.

The European governments accredited in Mexico have no political interests in that country, but they have large commercial ones and large colonies. France has $\$ 900,000,000$ invested in banking and manufacturing enterprises. Great Britain has close upon a billion of dollars invested in mines, banks, railways and plantations. Germany and Spain have each over $\$ 500,000,000$ invested in the country at large. The representatives of these governments have experienced, not only nearly two years of the misgovernment, but also the terrors and insincerities of the Madero government-a government in theory totally unsuited to Mexico, and in practice worse than the autocracy of General Diaz. They desired to provide for the safety of their nationals and to secure for them an opportunity to pursue their peaceful occupations. They therefore recommended the recognition of the Huerta government, and for those reasons only their representations were approved and acted upon by their governments. The refusal of this government to accord recognition became therefore 
equivalent to a rebuke to the European, Asiatic and Latin-American nations which had accorded recognition. This implied rebuke was distressing to them not only because they were deprived of the moral support of this government in aiding the Huerta administration to restore order, but because they were offered no compensation for the loss of the benefits expected to flow from their action. Mexico.

5. The attempt to destroy the financial credit and standing in

This was the second act of intervention in the affairs of Mexico, designedly expected to prevent the Huerta government from securing the means necessary to put down rebellion and disorder. For the purpose of carrying out this policy this government and this nation were made responsible for the destruction of vast material interests, for a protracted period of bloody warfare, for the unnecessary sacrifice of thousands of human lives, and for the permanent impairment of cordial good feeling between the two nations. This polioy, initiated without any knowledge of the resources of the Mexican government, has been a ridiculous failure. Huerta's revenues today are larger than they were six months ago. They are composed of $\$ 5,000,000$ a month from the customs revenue, and $\$ 6,000,000$ from special taxes that are not burdensome, thus giving a total revenue of $\$ 11,000,000$ a month to be used for administrative and war purposes.

6. The lifting of the embargo on the importation of arms and ammunition into Mexico.

This was an error (a) because it was dictated by considerations of "expediency" and not of "morals." Placing arms in the hands of civilized people bent on destroying one another is an immoral act and contrary to laws human and divine. How much more reprehensible, therefore, is the placing of arms in the hands of savages and vandals with the power to take human life and destroy the property of law-abiding people. By this policy our government, acting upon the promptings of mistaken even though honest motives, became accessory to the crimes committed by the hands of barbarians. (b) Because the act convicts the administration of insincerity, since the President some six months ago announced his determination never to take this step. (c) Because, with the failure of some established Mexican government to become responsible for damages growing out of the disturbed conditions existing in northern Mexico, we as a nation will become liable, under international law and under the interpre- 
tation of the Monroe Doctrine, for money compensation for the lives and property of foreigners taken in that territory. These damages will amount to probably seventy-five or one hundred millions of dollars.

7. The assumption that constitutional elections can be held in Mexico.

There has never been a constitutional election in Mexico, and there never will be until a radical change is made in the habits and character of the people. The work of making the nation democratic must be begun at the bottom and not at the top. We cannot justly saddle an ignorant nation with responsibilities such as are borne with difficulty by highly civilized nations. Eighty per cent of the population is Indian, unable to read or write, and having no comprehension of the theory and practice of democracy. As well expect the statue of liberty in New York harbor to stand if built upon quicksand as to expect a constitutional election under present conditions in Mexico. Every government there has been shot in and shot out of power, and a revolution is an election. The truth of this view is sustained by the history of Mexico since the time of the revolution against Spain. Where else throughout the world have there been more turbulence, more violent overturning of government, more hallelujahs of triumph, or more anathemas of death and defeat? The hero and patriot of one hour becomes in the next hour the fugitive from justice with a price upon his head. He who rules marches through slaughter to a throne. Power is seized by ambitious hands, but the victor ends his career in the dungeon, in exile, or by the dagger. From the time of the revolution against Spain down to the time of the establishment of the government of General Diaz, the rulers of Mexico pass across the stage like the ghosts of Banquo. The ambitious Iturbide, the tyrant Santa Anna, and the unhappy and misguided Maximilian, along with a multitude of vulgar and bloody tyrants, held sway over the destinies of this unhappy country, despoiling its population and leaving in their wake only the tragic echoes of disappointed ambitions. Philosophers should have learned the lesson taught in the pages of Mexico's bloody history, that the practice of democracy, which is a burden at times to the most civilized nations, cannot be successfully imposed upon an illiterate nation clothed only with superficial vestments of modern civilization.

Notw. This paper was read at a meeting of the Academy April 3, 1914. 